\title{
Effect of Material Composition on Thermal Stability Analysis of Coated and Uncoated FeCrAl CATCO by $\gamma-\mathrm{Al}_{2} \mathrm{O}_{3}$ Ultrasonic-Electroplating Technique
}

\author{
Dafit Feriyanto $^{1^{*}}$, Samir Sani Abdul Malik ${ }^{2}$, Muhamad Fitri ${ }^{1}$, Imam Hidayat ${ }^{1}$, \\ Hadi Pranoto ${ }^{1}$, Supaat Zakaria ${ }^{3}$
}

${ }^{1}$ Department of Mechanical Engineering, Faculty of Engineering,

Universitas Mercu Buana, Meruya Selatan, Jakarta, 11650, INDONESIA

${ }^{2}$ Department of Mechanical Engineering, Faculty of Engineering and Technology,

Nigerian Army University, Biu, Borno State, PMB 1500, NIGERIA

${ }^{3}$ Department of Mechanical Engineering,

Politeknik Ungku Omar, Jalan Raya Musa Mahadi, Ipoh, Perak, 31400, MALAYSIA

*Corresponding Author

DOI: https://doi.org/10.30880/jsmpm.2021.01.01.001

Received 01 October 2021; Accepted 20 November 2021; Available online 08 December 2021

\begin{abstract}
Catalytic Converter (CATCO) material become an interesting field to investigate due to the common CATCO material being ceramic material that has high brittleness than metallic materials. Therefore, this research investigates the $\mathrm{FeCrAl}$ metallic material as $\mathrm{CATCO}$ substrate that is coated by $\gamma-\mathrm{Al}_{2} \mathrm{O}_{3}$ as a washcoat, Nickel Oxide $(\mathrm{NiO})$ as a catalyst. The coating analysis was performed by ultrasonic using a frequency of $35 \mathrm{kHz}$ and various ultrasonic times of $1,1.5,2,2.5$, and 3 hours and electroplating technique by sulphamate types electrolyte using variation times of $15,30,45,60$, and 75 minutes, a current density of $8 \mathrm{~A} / \mathrm{dm}^{2}$. The result shows that the raw material was consists of $\mathrm{Fe}, \mathrm{Cr}$ and $\mathrm{Al}$ with $\mathrm{Fe}$ element was dominated for $74.13 \mathrm{wt} \%$. Coated sample by ultrasonic consists of $\mathrm{Fe}, \mathrm{Cr}, \mathrm{Al}, \mathrm{O}$, and $\mathrm{C}$ elements due to $\mathrm{FeCrAl}$ substrate was deposited by $\gamma-\mathrm{Al}_{2} \mathrm{O}_{3}$ powder and by electroplating technique consists of $\mathrm{Fe}, \mathrm{Cr}, \mathrm{Al}, \mathrm{O}, \mathrm{C}, \mathrm{Ni}$ and $\mathrm{Na}$ elements due to $\mathrm{NiO}$ deposition as catalyst material. TGA analysis observed that the highest mass change was observed by raw material $23.39 \mathrm{mg}$ and UB+EL $30 \mathrm{~min}$ samples for lowest mass change of $2.85 \mathrm{mg}$ with a point of the reaction is $0.07 \mathrm{mg} / \mathrm{min}$ may be caused by a protective oxide layer that developed during the coating process. Therefore, the coated metallic CATCO has a promising prospect to replace the ceramic CATCO due to high thermal stability by protecting layer and low mass change.
\end{abstract}

Keywords: Catalytic converter, metallic material, thermal stability, ultrasonic, electroplating

\section{Introduction}

The metallic CATCO was interesting component to explore as compared to ceramic materials due to its cheaper, high ductility and high thermal stability up to $1500{ }^{\circ} \mathrm{C}$. The $\mathrm{FeCrAl}$ is generally considered as metallic substrates in this research due to their advantage in the high thermal stability, high corrosion resistance, including the strong adherence of oxide film on the surface of substrate when applied the appropriate surface treatment [1,2]. The existing of excellent oxidation catalyst materials was usually based on the precious metal (Platinum (Pt), Palladium (Pd), and Rubindium $(\mathrm{Rd})$ ). However, those materials are expensive, high specific activity, limited supply, easily oxidized and easily broken 
at temperature of $500-900{ }^{\circ} \mathrm{C}$ [3]. The cheaper ranges of oxides $\left(\mathrm{CuO}, \mathrm{V}_{2} \mathrm{O}_{5}, \mathrm{NiO}, \mathrm{MoO}_{3}\right.$, and $\left.\mathrm{Cr}_{2} \mathrm{O}_{3}\right)$ compared to precious metals are being investigated as alternative catalyst $[3,4]$.

Ultrasonic is the technique to achieve finer surface structure and breaking the agglomerate. At low intensity, the wave will induce motion and mixing, a process called by acoustic streaming [5]. At higher intensities, ultrasonic propagated by oscillating pressure waves that alternately stretch and compress the liquid, thereby creating during expansion tiny micro bubbles or cavities which then collapse during compression. The ultrasonic frequencies which commonly performed for processing material between $16 \mathrm{kHz}$ to $2 \mathrm{MHz}$ where the sonochemistry principle is shown in Fig. 1.

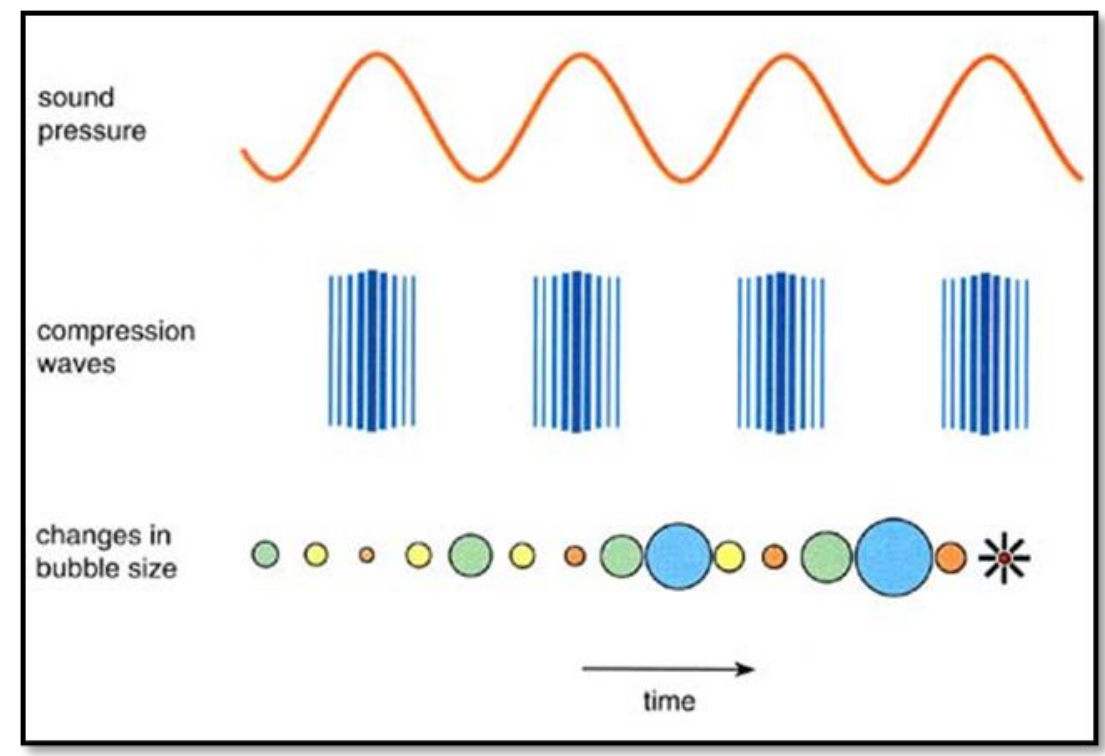

Fig. 1 - Principle of ultrasonic process [6]

Studied by Panin et al. [7] used the exciting ultrasonic oscilation by amplitude and frequency of $15 \mu \mathrm{m}$ and $24 \mathrm{kHz}$ within a treating tool and the other study that used the frequency of $25 \mathrm{kHz}$ and $100 \mathrm{~W}$, respectively for treating the surface of $\mathrm{Mg}(\mathrm{OH})_{2}$ [8]. Ultrasonic bath was successfully investigated by Kim et al. [5] and Chandni and Arthur [9]. They used ceramic washcoat such as $\mathrm{Al}_{2} \mathrm{O}_{3}$ and $\gamma-\mathrm{Al}_{2} \mathrm{O}_{3}$ and metallic substrate is FeCrAl for CATCO development.

Some coating technology for coating the substrate has been investigated by previous researchers such as dip coating [10], co-precipitation, spray-pyrolysis and sol-gel methods [11], electrophoretic deposition [12], aluminizing technique [13] and Solution Combustion Synthesis (SCS) [14]. Those techniques are successfully conducted, however there are limitations in applying the catalyst in the powder form. Currently, electroplating technique is one of the most promising technique in coating technique. Electrodeposition process of hybrid coating was investigated by Wua et al. [15]. Electrodeposition material of $\mathrm{Co}-\mathrm{Ni}-\mathrm{Al}_{2} \mathrm{O}_{3}$ using sulphamate type of electrolyte is applied into the electroplating process where the effect of ratio on the composition, $\mathrm{pH}$, morphology and magnetic properties of $\mathrm{Co}-\mathrm{Ni}-\mathrm{Al}_{2} \mathrm{O}_{3}$ thin film from a glycine bath is investigated. The results show that the appropriate condition to obtain a good coating by maximizing alumina content. Therefore, $\mathrm{Al}_{2} \mathrm{O}_{3}$ potential as electrodeposition material on $\mathrm{FeCrAl}$ substrate [16,17]. Moreover, $\gamma-\mathrm{Al}_{2} \mathrm{O}_{3}$ powder is more challenged to explore as coating material as investigated by Kim et al. [5]. In this research will be applied the $\mathrm{FeCrAl}$ substrate, $\gamma-\mathrm{Al}_{2} \mathrm{O}_{3}$ washcoat and $\mathrm{NiO}$ catalyst and it coated by combination technique between ultrasonic and electroplating that believe will be improve the CATCO properties in terms of high thermal stability due to protective oxide layer development during the coating process.

\section{Research Methodology}

The raw materials of this study were $\mathrm{FeCrAl}$ foils as substrate, $\gamma-\mathrm{Al}_{2} \mathrm{O}_{3}$ as a washcoat material, Nickel Oxide (NiO) plate and electrolyte solution. The FeCrAl that not performed by any coating activity was called by raw material. The $\mathrm{FeCrAl}$ and $\gamma-\mathrm{Al}_{2} \mathrm{O}_{3}$ that coated by ultrasonic bath was called by UB samples. The $\mathrm{FeCrAl}, \gamma-\mathrm{Al}_{2} \mathrm{O}_{3} \& \mathrm{NiO}$ that coated by ultrasonic bath combined with electroplating technique was called by UB+EL samples. The $\mathrm{FeCrAl}, \gamma-\mathrm{Al}_{2} \mathrm{O}_{3}$ and $\mathrm{NiO}$ that coated by electroplating technique was called by EL samples.

Ultrasonic bath, electroplating, combination of ultrasonic and electroplating were conducted to FeCrAl foil which cut in size of $40 \mathrm{~mm} \times 20 \mathrm{~mm}$ and $\gamma-\mathrm{Al}_{2} \mathrm{O}_{3}$ powder. During ultrasonic process, the frequency of $35 \mathrm{kHz}$ and various ultrasonic times of 1, 1.5, 2, 2.5 and 3 hours is imposed. Electroplating process is conducted through some components such as electrolyte, anti-pitting agent, anode and cathode. Sulphamate type which consists of nickel (ii) sulphate 6hydrate $\left(\mathrm{NiSO}_{4} \cdot 6 \mathrm{H}_{2} \mathrm{O}\right)$, nickel (ii) chloride $\left(\mathrm{NiCl}_{2} \cdot 6 \mathrm{H}_{2} \mathrm{O}\right)$, boric acid $\left(\mathrm{H}_{3} \mathrm{BO}_{3}\right)$, and sodium dodecyl sulfate 
$\left(\mathrm{C}_{12} \mathrm{H}_{25} \mathrm{OSO}_{3} . \mathrm{Na}\right)$. A nickel (Ni) plate substrate acted as anode with the size of $50 \mathrm{~mm}$ x $10 \mathrm{~mm}$, whereas a $\mathrm{FeCrAl}$ acted as cathode with the size of $40 \mathrm{~mm} \times 20 \mathrm{~mm}$. The distance between anode and cathode was adjusted at $25 \mathrm{~mm}$. The electroplating was conducted for several variation times of $15,30,45,60$, and 75 minutes, current density of 8 $\mathrm{A} / \mathrm{dm}^{2}, 3 \mathrm{~g} \gamma-\mathrm{Al}_{2} \mathrm{O}_{3}$ inserted into the beaker for each sample and total surface area of $1600 \mathrm{~mm}^{2}$ in two sides. Analysis that conducted in this research is Scanning Electron Microscope (SEM)-Electron Dispersive Spectroscopy (EDS) (JEOL, JSM-6380LA, Japan) for composition investigation. High Vacuum (HV) mode is used in SEM process with Secondary-Electron Image (SEI) detector will be emitted from inelastic collisions with electrons in the k-orbital of the specimen's atoms. Thermo Gravimetric Analysis (TGA) (LINSEIS, L81/1550, Germany) for investigating the thermal stability of coated and uncoated material that conducted at temperature of $1000{ }^{\circ} \mathrm{C}$ with heating rate and cooling rate of $100{ }^{\circ} \mathrm{C}$ per minutes. This temperature was performed due to the maximum temperature of exhaust emission system in gasoline engine in the range of $800-850{ }^{\circ} \mathrm{C}$. The samples were measured by using microbalance with accuracy of 0.1 $\mathrm{mg}$ and then the samples put into TGA machine.

\section{Results and Discussion}

\subsection{Composition Analysis}

Composition analysis were performed on the coated $\mathrm{FeCrAl}$ by $\gamma-\mathrm{Al}_{2} \mathrm{O}_{3}$ powder and $\mathrm{NiO}$ catalyst using several methods such as Ultrasonic Bath (UB), Ultrasonic Bath + Electroplating (UB+EL) and Electroplating (EL) Technique. From EDS analysis was observed the composition of coated and uncoated FeCrAl. SEM and EDS characterization are performed after the coated and uncoated $\mathrm{FeCrAl}$ is heated at high temperature operation of $1000{ }^{\circ} \mathrm{C}$ that purposed to activate protective oxide layer and to eliminate the other chemical agent which embedded during coating process.

\section{(a) Raw Materials and UB Samples}

Composition analysis of $\mathrm{FeCrAl}$ substrate as raw material and coated $\mathrm{FeCrAl}$ by $\gamma-\mathrm{Al}_{2} \mathrm{O}_{3}$ powder using ultrasonic technique as listed in Table 1. Raw material mainly consists of three major elements of $\mathrm{Fe}, \mathrm{Cr}$ and $\mathrm{Al}$ with $\mathrm{Fe}$ element was dominated for $74.13 \mathrm{wt} \%$. The composition of UB samples mainly consists of $\mathrm{Fe}, \mathrm{Cr}, \mathrm{Al}, \mathrm{O}$ and $\mathrm{C}$ due to $\mathrm{FeCrAl}$ substrate was deposited by $\gamma-\mathrm{Al}_{2} \mathrm{O}_{3}$ powder. In composition analysis, $\mathrm{Fe}$ and $\mathrm{Cr}$ were dominated in each sample for 60.52-65.13 wt\% and 16.55-18.66 wt\%. Therefore, the material has high temperature range operation. In UB samples C content was increased that caused by heating process after ultrasonic process to drain the samples from ethanol as electrolyte. Oxygen content also increase which caused by oxygen cavitation on the $\gamma-\mathrm{Al}_{2} \mathrm{O}_{3}$ coating layer which can approved by surface morphology analysis [16]. In addition, the increment of $\mathrm{Al}, \mathrm{Cr}$ and $\mathrm{Fe}$ content because it activated by ultrasonic technique by collisions during the process and also because it has main components of $\mathrm{FeCrAl}$ fabrication.

Table 1 - Composition analysis of raw material and UB samples

\begin{tabular}{|c|c|c|c|c|c|}
\hline \multirow{2}{*}{ Sample name } & \multicolumn{5}{|c|}{ Elements (wt\%) } \\
\hline & $\mathbf{C}$ & $\mathbf{O}$ & Al & $\mathrm{Cr}$ & $\mathbf{F e}$ \\
\hline Raw & - & - & 5.62 & 20.25 & 74.13 \\
\hline UB $1 \mathrm{~h}$ & 13.45 & 4.6 & 4.87 & 16.55 & 60.52 \\
\hline UB $1.5 \mathrm{~h}$ & 9.16 & 3.58 & 4.91 & 17.22 & 65.13 \\
\hline UB $2 \mathrm{~h}$ & 9.91 & 3.03 & 4.61 & 18.60 & 63.85 \\
\hline UB $2.5 \mathrm{~h}$ & 8.93 & 3.07 & 5.03 & 18.33 & 64.63 \\
\hline UB $3 \mathrm{~h}$ & 9.15 & 4.38 & 4.94 & 18.66 & 62.88 \\
\hline
\end{tabular}

The composition analysis of raw material and UB samples highly related with compound analysis that observed the several compound that developed during washcoat process. In UB samples has several compounds such as FeCrAl, $\mathrm{FeO}, \gamma-\mathrm{Al}_{2} \mathrm{O}_{3}$ and $\mathrm{FeCr}_{2} \mathrm{O}_{3}$. FeCrAl and $\gamma-\mathrm{Al}_{2} \mathrm{O}_{3}$. That compounds increased the thermal stability by lower mass change as compared with raw material for $17.46 \mathrm{mg}$. This property will be given high impact on improving the CATCO endurance in exhaust emission system that operate in high temperature and extreme condition. According to Jung and Bae [18], the maximum range of exhaust temperature in exhaust emission system was $\leq 800$ to $850{ }^{\circ} \mathrm{C}$.

\section{(b) EL Samples}

Composition analysis of EL samples with various time of 15, 30, 45, 60, and $75 \mathrm{~min}$ as listed in Table 2. This technique was conducted by sulphamate type solution, $\mathrm{NiO}$ as anode and $\mathrm{FeCrAl}$ as cathode as well as $\gamma-\mathrm{Al}_{2} \mathrm{O}_{3}$ as coating material. The composition of EL samples mainly consists of 7 elements such as $\mathrm{Fe}, \mathrm{Cr}, \mathrm{Al}, \mathrm{O}, \mathrm{C}, \mathrm{Ni}$, and $\mathrm{Na}$ elements. The range of composition for each element was 52.56-63.54 wt\% for Fe element, $\mathrm{Al}$ for 3.56-11.89 wt\%, $\mathrm{Cr}$ 
for 14.97-18.56 wt \%, O for 2.47-11.78 wt\%, C for 8.33-11.85 wt\%, Na for 0.11-0.48 wt\% and Ni for 0.17- $1.58 \mathrm{wt} \%$. The element was dominated by $\mathrm{Fe}$ and $\mathrm{Cr}$ elements with high weight percentage in each sample. In addition, $\mathrm{Na}$ and $\mathrm{Ni}$ also present in EL samples which play the important role when the coated material is performed in high temperature of $1000{ }^{\circ} \mathrm{C}$ [19]. That data was approved by compound analysis that those elements develop some compounds such as $\mathrm{FeCrAl}, \mathrm{FeO}, \gamma-\mathrm{Al}_{2} \mathrm{O}_{3}, \mathrm{FeCr}_{2} \mathrm{O}_{3}, \mathrm{NiO}, \mathrm{NiAlO}_{4}, \mathrm{NiCr}_{2} \mathrm{O}_{4}$ and $\mathrm{NaO}_{2}$. Interaction between $\gamma-\mathrm{Al}_{2} \mathrm{O}_{3}$ and FeCrAl substrate is related to the diffusion activity where the alumina scale grows exclusively by oxygen diffusion along grain boundaries. Higher $\mathrm{Al}$ content and $\mathrm{O}$ content will promote higher diffusion phenomena of the samples [20].

Table 2 - Composition analysis of EL samples

\begin{tabular}{lccccccc}
\hline \multirow{2}{*}{ Sample name } & \multicolumn{7}{c}{ Elements (wt\%) } \\
& $\mathbf{O}$ & $\mathbf{C}$ & Al & $\mathbf{C r}$ & $\mathbf{F e}$ & $\mathbf{N a}$ & $\mathbf{N i}$ \\
\hline EL 15 min & 2.47 & 11.85 & 3.56 & 18.43 & 63.04 & 0.48 & 0.17 \\
EL 30 min & 2.96 & 8.33 & 4.92 & 18.56 & 63.54 & 0.11 & 1.58 \\
EL 45 min & 5.2 & 10.75 & 4.13 & 16.47 & 62.66 & 0.28 & 0.52 \\
EL 60 min & 11.78 & 10.65 & 7.74 & 16.09 & 53.83 & 0.42 & 0.51 \\
EL 75 min & 10.46 & 9.23 & 11.89 & 14.97 & 52.56 & 0.14 & 1.03 \\
\hline
\end{tabular}

Coating activity and coating layer believe has high diffusion of $\gamma-\mathrm{Al}_{2} \mathrm{O}_{3}$ to the $\mathrm{FeCrAl}$ substrate since there is cation and anion transport which led to higher diffusion coefficient [20]. The compounds that has been observed shown promising improvement on substrate properties in high thermal stability at high temperature application up to $1000{ }^{\circ} \mathrm{C}$ that supported by thermal stability analysis that EL samples has lower mass change of $3.99 \mathrm{mg}$ as compared with raw material and UB samples that promote protective oxide layer on FeCrAl.

\section{(c) UB+EL Samples}

Combination of Ultrasonic and Electroplating Technique (UB+EL) has successfully performed to coat FeCrAl material by using $\gamma-\mathrm{Al}_{2} \mathrm{O}_{3}$ and $\mathrm{NiO}$ in order to develop more protective oxide layer in high temperature operation and long-term operation. UB+EL samples for various holding time of 15, 30, 45, 60, and 75 minutes as listed in Table 3. Elements that were observed after UB+EL technique such as Fe, Cr, Al, O, C, Ni, and Na elements. Therefore, based on compound analysis, $\mathrm{UB}+\mathrm{EL}$ samples develop some compounds as protective oxide layer that consists of $\mathrm{CrAl}, \mathrm{FeO}$, $\gamma-\mathrm{Al}_{2} \mathrm{O}_{3}, \mathrm{FeCr}_{2} \mathrm{O}_{3}, \mathrm{NiO}, \mathrm{NaO}_{2}, \mathrm{NiAl}_{2} \mathrm{O}_{4}$ and $\mathrm{NiCr}_{2} \mathrm{O}_{4}$. The composition of UB+EL samples in the range of 55.95-60.63 wt $\%$ for Fe element, $\mathrm{Al}$ for 5.85-9.23 wt\%, Cr for 16.33-19.54 wt\%, O for 4.57-8.36 wt\%, C for 8.8-13.43 wt \%, Na for $0.03-0.55 \mathrm{wt} \%$, and $\mathrm{Ni}$ for $0.17-0.62 \mathrm{wt} \%$. Ni has developed because there is diffusion mechanism between Ni as anode and $\mathrm{FeCrAl}$ as cathode when Ni-electroplating process.

Table 3 - Composition analysis of UB+EL samples

\begin{tabular}{cccccccc}
\hline \multirow{2}{*}{ Sample name } & \multicolumn{7}{c}{ Elements (wt\%) } \\
& $\mathbf{O}$ & $\mathbf{C}$ & Al & $\mathbf{C r}$ & $\mathbf{F e}$ & $\mathbf{N a}$ & $\mathbf{N i}$ \\
\hline UB+EL 15 min & 8.36 & 9.95 & 9.23 & 16.33 & 55.95 & 0.41 & 0.25 \\
UB+EL 30 min & 5.49 & 13.43 & 6.03 & 16.59 & 57.88 & 0.03 & 0.62 \\
UB+EL 45 min & 5.32 & 10.41 & 6.37 & 17.9 & 58.84 & 0.55 & 0.6 \\
UB+EL 60 min & 5.22 & 12.51 & 5.85 & 17.35 & 59.16 & 0.09 & 0.17 \\
UB+EL 75 min & 4.57 & 8.8 & 5.93 & 19.54 & 60.63 & 0.32 & 0.22 \\
\hline
\end{tabular}

Composition analysis of UB+EL samples shows the important of elements in the samples to increase the properties of material such as thermal stability due to compound development during the coating process. UB+EL samples has smallest mass change of $2.85 \mathrm{mg}$ that indicated the material has highest thermal stability as compared with raw material, UB and EL samples.

\subsection{Thermal Stability of Coated and Uncoated FeCrAl}

Thermal stability analysis was conducted using Thermo Gravimetric Analysis (TGA) to investigate the effect of the treatment on the thermal stability in high temperature. Thermal stability is shown by low mass change while operated in high temperature of $1000{ }^{\circ} \mathrm{C}$. Mass change of coated and uncoated $\mathrm{FeCrAl}$ substrate quite related to the mass change derivative because it shows the gradation and degradation mass in each temperature. Raw material shows 
the highest mass change as compared with coated material which indicated that it has lowest thermal stability that caused by $\mathrm{FeCrAl}$ is unprotected by any oxide protective layer such as $\mathrm{Cr}_{2} \mathrm{O}_{3}, \mathrm{FeO}, \mathrm{NiO}$, and $\gamma-\mathrm{Al}_{2} \mathrm{O}_{3}$.



Fig. 2 - Mass change of coated and uncoated samples

The lowest mass change and highest mass change derivative of UB samples in each treatment is shown Fig. 2 and Fig. 3 were located at UB $1.5 \mathrm{~h}$ for $17.46 \mathrm{mg}$ and $0.03760 \mathrm{mg} /{ }^{\circ} \mathrm{C}$, for UB+EL $30 \mathrm{~min}$ samples $2.85 \mathrm{mg}$ and 0.01000 $\mathrm{mg} /{ }^{\circ} \mathrm{C}$ and for EL $30 \mathrm{~min}$ samples of $3.99 \mathrm{mg}$ and $0.01000 \mathrm{mg} /{ }^{\circ} \mathrm{C}$. Comparison between treatments regarding to the mass change and mass change derivative is shown that UB+EL $30 \mathrm{~min}$ sample has the lowest mass change and mass change derivative relatively high because it have a high protective oxide scale formed by inside diffusion of chromium $\left(\mathrm{Cr}^{2-}\right)$. It supported by compound analysis that UB+EL 30 min developed some compounds such as $\mathrm{FeCrAl}, \mathrm{FeO}, \gamma-$ $\mathrm{Al}_{2} \mathrm{O}_{3}, \mathrm{FeCr}_{2} \mathrm{O}_{3}, \mathrm{NiO}, \mathrm{NaO}_{2}, \mathrm{NiAl}_{2} \mathrm{O}_{4}$ and $\mathrm{NiCr}_{2} \mathrm{O}_{4}$. The distribution of oxide scale in the sample is needed to improve the mechanical properties of coated $\mathrm{FeCrAl}$ substrate and to reduce the change effects of the material condition from ductile to brittle [21].

Fig. 2 shows that raw material has the highest mass change is compared with coated materials. The lowest mass changes as shown by UB+EL $30 \mathrm{~min}$ sample and followed by EL $30 \mathrm{~min}$. Lower mass change is indicated that the material have higher thermal stability because high protective oxide scale based on EDS analysis such as $\mathrm{FeCrAl}, \mathrm{FeO}$, $\gamma-\mathrm{Al}_{2} \mathrm{O}_{3}, \mathrm{FeCr}_{2} \mathrm{O}_{3}, \mathrm{NiO}, \mathrm{NiAlO}_{4}, \mathrm{NiCr}_{2} \mathrm{O}_{4}$, and $\mathrm{NaO}_{2}$ developed through this method. That compounds developed because reaction when ultrasonic treatment through its cavitation which make finer $\gamma-\mathrm{Al}_{2} \mathrm{O}_{3}$ coated layer and electroplating technique through reaction between anode and cathodes by sulphamate electrolyte.

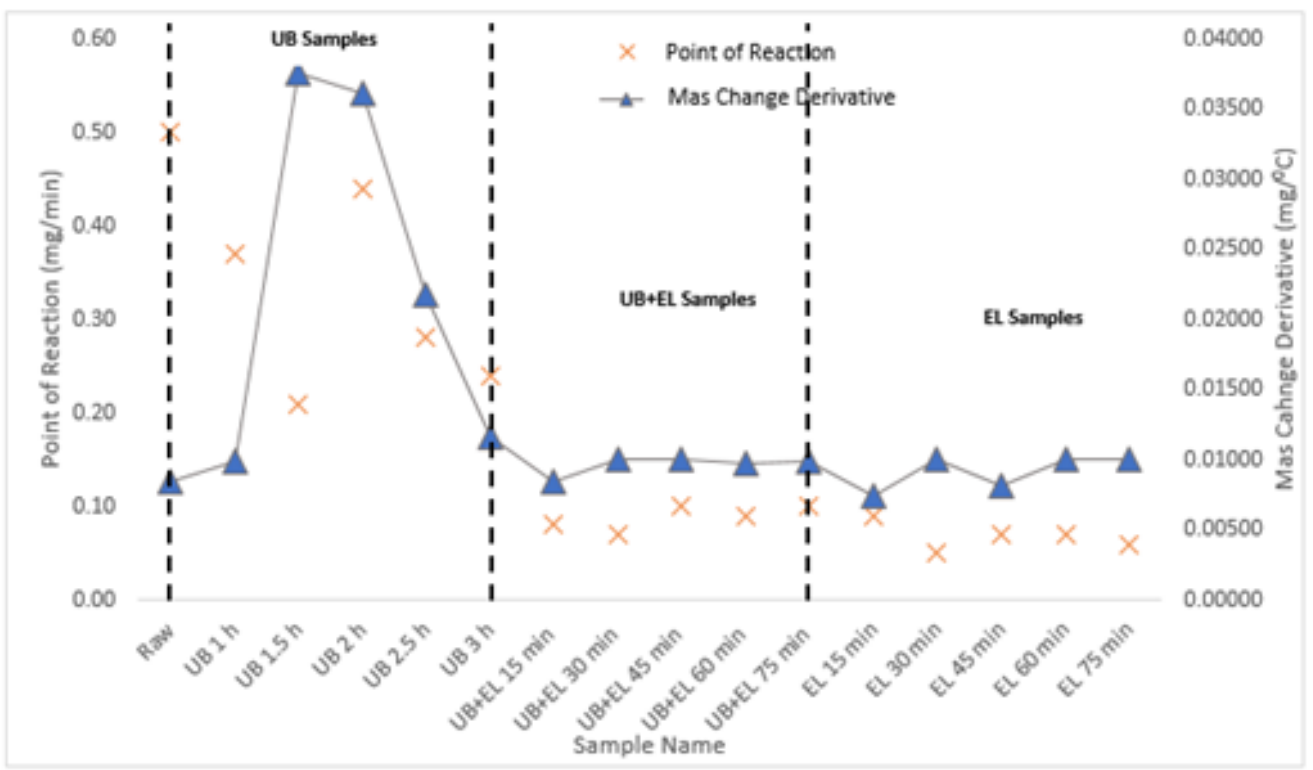

Fig. 3 - Mass change derivative and point of reaction of coated and uncoated samples 
The unstable mass change derivative and point of reaction for all samples as shown in Fig. 3. There are gradation and degradation during the TGA analysis. First condition is the oxidation (gradation mass) of mass change derivative was observed when the compound formed by the reaction with oxygen or oxygen bonding has occurred. The mass change derivative has increased which occurs in temperature of $110.97-330.42{ }^{\circ} \mathrm{C}, 540.79-709.49{ }^{\circ} \mathrm{C}$, and 793.87 $878.29{ }^{\circ} \mathrm{C}$. Second condition is the degradation of mass change derivative due to the decreasing oxygen bonding [22]. Degradation was occurred in range temperature of $331.42-498.69^{\circ} \mathrm{C}$ and $879.29-960{ }^{\circ} \mathrm{C}$, respectively.

\section{Conclusion}

The coating process by ultrasonic and electroplating was very effective to embedded the $\gamma-\mathrm{Al}_{2} \mathrm{O}_{3}$ washcoat and $\mathrm{NiO}$ catalyst on FeCrAl substrate that observed by SEM analysis. The coated samples were consisting of several elements and lead the increment of $\mathrm{C}, \mathrm{O}, \mathrm{Al}, \mathrm{Cr}, \mathrm{Fe}, \mathrm{Na}$, and $\mathrm{Ni}$ as compared with raw material. That increment causes the thermal stability increased as compared to raw material, where the lowest thermal stability observed by UB+EL 30 min for lowest mass change of $2.85 \mathrm{mg}$ with point of reaction is $0.07 \mathrm{mg} / \mathrm{min}$. It means that the coating technique by ultrasonic and electroplating very recommended to increase the thermal stability of CATCO material and promising CATCO material to replace the ceramic CATCO material.

\section{Acknowledgement}

This research was supported by Mercu Buana University, Jakarta and our colleagues from Universiti Tun Hussein Onn Malaysia for their expertise that greatly assisting this research.

\section{References}

[1] Pilone, D. (2009). Ferritic Stainless Steels for High Temperature Applications in Oxidizing Environments. Recent Patents on Materials Science, 2(1), pp. 27-31.

[2] Checmanowski, J. G. \& Szczygiel, B. (2008). High Temperature Oxidation Resistance of FeCrAl Alloys Covered with Ceramic SiO2-Al2O3 Coatings Deposited by Sol-gel Method. Corrosion Science, 50(12), pp. 3581-3589.

[3] Bagus, I. R. M., Purwanto, P. \& Hadiyanto, H. (2015). Optimum Design of Manganese-Coated Copper Catalytic Converter to Reduce Carbon Monoxide Emissions on Gasoline Motor. Procedia Environmental Sciences, 23, pp. $86-92$.

[4] Kolaczkowski, S. (2006). Treatment of Volatile Organic Carbon (VOC) Emissions from Stationary Sources: Catalytic Oxidation of The Gaseous Phase. In: Structured Catalysts and Reactors, 2nded, A. Cybulski. \& J. A. Moulijn, (Eds.), 147-169, Taylor \& Francis Group, ISBN 0-8247-2343-0, Boca Raton, FL.

[5] Kim, D. H., Yu, B. Y., Cha, P. R., Yoon, W. Y., Byun, J. Y., \& Kim, S. H. (2012). A study on FeCrAl foam as effective catalyst support under thermal and mechanical stresses. Surface and Coatings Technology, 209, $169-176$.

[6] ASM Handbook. (1994). Ultrasonic Cleaning. Vol. 5, Surface Engineering, p 44-47, ASM International, Materials Park, OH 44073-0002.

[7] Panin, A. V., Klimenov, V. A., Pochivalov, Y. I., Son, A. A. \& Kazachenok, M. S. (2004). The effect of ultrasonic treatment on mechanical behaviour of titanium and steel specimens. Theoretical and Applied Fracture Mechanics, 41, pp. 163-172.

[8] Zhang, F., Zhang, H. \& Su, Z. (2007). Surface treatment of magnesium hydroxide to improve its dispersion in organic phase by the ultrasonic technique. Applied Surface Science, 253, pp. 7393-7397.

[9] Chandni, R. \& Arthur, G. (2014). Growth of Hierarchically Structured High-Surface Area Alumina on FeCr alloy®Rods. Chinese Journal of Chemical Engineering, 22, pp. 861-868.

[10] Jia, L., Shen, M. \& Wang, J. (2007). Preparation and characterization of dip-coated $\gamma$-alumina based ceramic materials on FeCrAl foils. Surface \& Coatings Technology, 201(16-17), pp. 7159-7165.

[11] Yanqing, Z., Jieming, X., Cuiqing, L., Xin, X. \& Guohua, L. (2010). Influence of preparation method on performance of a metal supported perovskite catalyst for combustion of methane. Journal of Rare Earths, 28(1), pp. 54-58.

[12] Corni, I., Ryan, M. P. \& Boccaccini, A. R. (2008). Electrophoretic deposition: From traditional ceramics to nanotechnology. Journal of the European Ceramic Society, 28(7), pp. 1353-1367.

[13] Aya, S., Yingna, W., Akihiro, Y., Hideyuki, M., \& Catherine, M. F. (2007). Oxidation behavior of Pt-Ir modified aluminized coatings on Ni-base single crystal super alloy TMS-82+.Oxid Met., 68, pp. 53-64.

[14] Sebayang D., Untoro, P., Putrasari, Y., Soon, Y.H., Hashim, M. \& Gooma, M. (2009). Influence of difference deposition technique of nickel on the FeCrAl metallic monolith. Proceedings of the Malaysian Metallurgical Conference '09 (MMC'09), pp. 1-5.

[15] Wua, G., Lia, N., Zhoua, D. \& Mitsuo, K. (2004). Electrodeposited Co-Ni-Al2O3 composite coatings. Surface and Coatings Technology, 176(1), pp. 157-164.

[16] Masakuni, O., \& Kenichi, A. (2015). Effect of La modification on the stability of coating alumina layer on FeCrAl alloy substrate. Surface \& Coatings Technology, 271, pp. 80-86. 
[17] Jung, Y. \& Bae, C. (2015). Immaturity of soot particles in exhaust gas for low temperature diesel combustion in a direct injection compression ignition engine. Fuel, 161, pp. 312-322.

[18] Xiang, L., Gong, Y. L., Li, \& Wang, Z. W. (2004). Influence of hydrothermal modification on the properties of Ni/A12O3 catalyst. Applied Surface Science, 239, pp. 94-100.

[19] Heesemann, A., Schmidtke, E., Faupel, F., Kolb-Telieps, A. \& Klower, J. (1999). Aluminum and silicon diffusion in Fe-Cr-Al alloys. Scripta Materialia, 40(5), pp. 517-522.

[20] Fnidiki, A., Lemoine, C., \& Teillet, J. (2005). Properties of mechanically alloyed Fe100-x Crx powder mixtures: Mossbauer study. Physica, B 357, 319-325.

[21] Geng, S. J., Zhu, J. H. and Lu, Z. G. (2006). Evaluation of Haynes 242 alloy as SOFC interconnect material. Solid State Ionics, 177, pp. $559-568$.

[22] He, L., Fan, Y. L., Luo, L., Bellettre, J., Yue, J. (2020). Preparation of $\mathrm{Pt} / \gamma-\mathrm{Al}_{2} \mathrm{O}_{3}$ catalyst coating in microreactors for catalytic methane combustion. Chemical Engineering Journal, 380, pp. 122424. 